Sánchez López, José.

Artista-investigador independiente.

\title{
Inframedia: barreras infraestructurales y ecologías online en la Web 2.0.
}

\section{Inframedia: infraestructural barriers \\ and online ecologies on the Web 2.0.}

\author{
TIPO DE TRABAJO:
}

Comunicación.

PALABRAS CLAVE:

Esencialismo de interfaz visual, capas de abstracción, interactividad, medios computacionales, New Aesthetics.

KEY WORDS :

Screen essentialism, abstraction layers, interactivity, computational media, New Aesthetics.

\section{RESUMEN.}

Nuestra inteligencia colectiva y con ella nuestro posicionamiento "glocal" dependen estrechamente de la operación a gran escala de los media existentes en las redes (motores de búsqueda, redes sociales, Wikis etc.). El origen digital de tales medios, y su dependencia de las ciencias de la computación las hace adoptar formas distintivas en relación específica con el diseño de software. Dada esta situación, es importante señalar la condición limitada, particular a nuestro contacto fenomenológico y cognitivo con las infraestructuras de red que lo soportan.

El presente trabajo trata de resumir una investigación personal sobre la visualidad en las redes, que tiene por objetivo proveer de contexto teórico a una próxima experimentación artística en el ámbito de los nuevos medios. Ésta, órbita alrededor de una serie de cuestiones que surgen en relación con la noción de "interfaz cibernética", entendida como la parte visible de todo un complejo infraestructural.

Se destacan cuatro principales focos de incidencia: 1.Valoración de la estructura en capas de abstracción funcional, propias de la gestión mediada: arquitectura, protocolos y algoritmos que componen la "vida" tecno-material de la red. 2.La doble acepción de "colectividad" en las redes: la generación de contenidos por parte de usuarios, y su oscilación entre lo procomún y la recolección de datos. 3.Atención al término acuñado por James Bridle: "New Aesthetics", y la iniciativa de señalar la creciente autonomía de lo digital en su vocación de referir lo real desde sus propios términos. Circunstancia puesta en relación con las inquietudes de la sociología contemporánea por considerar la implicación de los agentes nohumanos en las dinámicas sociales propias de la ecología on-line. 4.Impacto sobre casos concretos: prácticas artísticas contemporáneas sujetas al contexto digital desde sus estrategias formales, sea en complicidad, o en actitud de resistencia en un ejercicio de contra-diseño. 


\section{ABSTRACT.}

Collective Intelligence and our notion of glocal position depend closely on the large existing media available on the Internet (search engines, social media, wikis...). Its digital origin and its dependency on computer science allow them to take different forms with specific relation to software design. That stated, it is important to underscore this situation encompasses our limited knowledge and phenomenological contact with the infrastructure that supports them.

This presentation works as a snapshot of an ongoing personal research about networks and visibility, whose main goal is to provide a theoretical context for the future development of a new media artistic project. The whole idea revolves around some topics that focus on the notion of interface being the visible part of an infrastructure complex.

The analysis is structured around four main themes: 1. Evaluation of the abstraction layers that techno-material "life" of the networks: architecture, protocols and algorithms are made of. 2. The dual meaning of "collective", when it comes to online interaction: creation of contents by users and how this oscillate between the commons production and data collection. 3 . Attention to the concept coined by James Bridle "New Aesthetics" and how the digital became autonomous in referring reality in its own terms. 4. The impact of this digital context on artistic contemporary strategies, from counter-design to complicity. 